\title{
THE STUDY OF THE SCIENCE OF MUNICIPAL GOVERNMENT.
}

As was well said by Professor Thorpe in a recent article,* "It is one labor to lay down the principles of representative government, it is another labor to administer these principles." The people of the United States may fairly claim to have accomplished the first of these tasks with credit; they are now struggling with the second, and are just beginning to realize its magnitude. In the century of their uational existence they have firmly established the scheme or framework of their government, but in the meanwhile social conditions have been undergoing radical changes. The inventions of modern science have broken down local barriers and destroyed to a large extent local independence. The control of accumulated capital by corporations has introduced a dangerous force into the operations of trade and commerce, and the phenomenal increase of large cities has introduced an equally dangerous factor into the domain of politics. The ordinary administrative machinery of the government, constructed for a less complex condition of society, is proving inadequate. A more scientific construction and a more systematic operation is imperative. This is the great problem of the day for the states as distinguished from the federal government. Every constitutional convention that meets (and they are only too frequent) is occupied, not with the discussion of principles of government, but with the attempt to remedy defects of administration. The efforts in this direction have been often crude and unscientific, but they serve to show that the subject is forcing itself upon the public attention.

\footnotetext{
* "Recent Constitution Making in the United States." Annals of the Am. Academy of Polit. and Social Science. September, I8gr.
}

$\left[45^{\circ}\right]$ 
Among these problems of administration, one of the most, if not the most important, is the problem of the economical and successful government of cities. The tendency of the age is toward city life. Already a large and constantly increasing proportion of our population live in cities. Few realize how great an effect this necessarily has upon the administration of the powers of government. The inhabitants of a city need, if I may use the expression, more government than the inhabitants of the rural districts. Both classes alike look to the state for protection in the rights guaranteed to them by the organic law of the Constitution; the undisturbed enjoyment of personal liberty and private property; the free exercise of speech and religion; the impartial administration of justice by the courts, and the right to administer certain local affairs. But with regard to the dense masses of population in large towns, the state is called upon to perform, in addition, other numerous and difficult duties. It must, either directly or through grants of public franchises, supply the citizens with water and light, must provide for the removal of their waste, must secure their safe and rapid transportation, must look after their health and safety by suitable regulations, and must protect them by a disciplined army of police.

The performance of these various functions requires the collection and expenditure of vast sums of money, the construction of enormous engineering works, the training and supervision of an immense number of employes. Scientific knowledge, skilled labor, systematic organization are all necessary for the conduct of the various municipal departments. The scale on which such operations are conducted, increases both the danger and consequences of a mistake. Inefficient sanitary regulations may cause a sudden epidemic, or what is perhaps worse, a gradual but steady increase of the death rate. Unskillful engineering may cause a water famine, or send the germs of disease into every household. Inadequate transportation facilities or unwise building laws may check the growth of the city or crowd its poorer inhabi- 
tants into tenements. Improper harbor regulations may drive commerce from its doors. Ignorant or dishonest financiering may bankrupt its treasury. In brief, the happiness and prosperity of that large portion of the population which lives in cities are directly dependent upon the administration by the government of functions which require very thorough scientific knowledge and very great scientific skill. I use the word "scientific" advisedly. Municipal government is a science by itself. As has been already pointed out, it involves the construction and maintenance of engineering and manufacturing works and the transaction of financial operations upon an immense scale, and this work is to be done, not under the ordinary conditions of business, but with due regard to various political and economic questions, which complicate the problem and add to its difficulty. The probable growth of the city, the social conditions which may affect its future needs, the probability of constant changes in its administrative force, the necessity for a scientific organization of the work which will enable it to be carried on with some uniformity in spite of such changes, the equitable distribution of expenses among the citizens themselves and between the present and future generations; all these are considerations which enter into the problem of municipal government and render its operation a science, involving, indeed, many branches of scientific knowledge, but possessing an individuality distinct from all of them. To understand and to apply this science requires a thorough knowledge, obtained by a careful study of past and existing facts ; an investigation of previous experiments, with their results; a comparison of observations, and the working out of rules of general application. This would seem almost self-evident, yet there has been in the past a general tendency to ignore this truth and to assume that all our difficulties of administration come from dishonesty in our officials. Year after year we spend a large part of our energy, and some of our substance in the vain attempt to elect first-class men by means of second-class political machinery, and when occa- 
sionally we succeed we flatter ourselves that we have solved the problem of municipal government, as if all its principles were so simple and so well understood that any man of ordinary business sagacity could administer them if only he were honest. The absurdity of this is apparent, if we consider for a moment the character of the problems which our city officials must solve. Shall the city manufacture its own gas and electricity, or allow the work to be done by private corporations under proper regulations? Shall the water supply be taken from a source near at hand, or remote? Shall the water be filtered? Shall the waste of the city be burned or conveyed away in sewers? If the latter, what sewerage system shall be adopted? Shall the city exercise control over all transportation lines within its limits; if so, what methods of transportation shall be adopted and under what restrictions? How shall the city be paved? How shall the cost of public works be assessed and collected? Shall the public moneys be kept in the city's own care, or shall they be deposited in private banks; and if the latter, what interest shall be paid? Shall the city do its work by contract or day's labor? How can the city's employes be so organized and supervised that careless or dishonest work can be at once detected. These are but a few of the difficult and complicated questions which are forcing themselves at the present time upon all our American municipalities. These are not questions which can be answered by any honest man of ordinary business experience and capacity. For their solution scientific knowledge is quite as requisite as honesty. It is time that we realized that many of the difficulties and mistakes of administration are due as much to ignorance as to corruption ; as much to unskilful and unscientific measures as to dishonest ones. That honesty in officials is essential to good government no one will deny; but it is also true that skill and knowledge are quite as essential, and that an ignorant and untrained official at the head of a municipal department may work as much injury as a dishonest one. There is also another consideration which must not be over- 
looked in dealing with this subject. A scientific organization of departments will, to a very large extent, increase the morality as well as the efficiency of the employes. Although the analogy is not quite perfect, the civil service of a community is not unlike an army. The average man has a reasonable amount of courage and no more. An army recruited from the generai mass of citizens may, by lax discipline and want of organization, be turned into a mob that will run panic-stricken at the first fire, or it may be so carefully disciplined and so thoroughly organized that it will face the enemy without flinching. So with the civil force; lack of discipline, absence of supervision, loose methods of administration, may offer opportunities to and develop whatever latent dishonesty may exist in the individual officeholder, while on the other hand, a thorough and scientific organization will decrease his temptations and strengthen his moral fibre. Whether, therefore, we view the question as one of expediency merely, or whether we hold with those reformers who decline to consider any question of municipal politics except the elevation of the moral tone of the community, the study of the science of municipal government seems to be of the highest importance.

How is this study to be pursued? The question is easy to ask, but very difficult to answer. There are those who hope at some time to see side by side with that great military establishment at which the nation trains its youth in the science of arms, an equally large and efficient institution for the training of students in the science of administrative government, with a prospect of employment in the civil service of the state, as permanent and honorable as that offered to the graduates of the military academy. When that time arrives we may also hope to see the states and municipalities establishing schools and offering scholarships for the purpose of filling their administrative offices with trained and competent men. Since the preference of our people is undoubtedly to fill the offices of state with men who have fought their way upward without 
the aid of wealth or social position, it seems only reasonable that the state should endeavor to open to such men avenues of education in that science in'which they can best serve the community. This, however, is as yet but a dream, and one that has no prospect of practical realization in this generation. The science of administrative government cannot yet be studied in public institutions or at public expense.

It is equally clear that, except in a very general way, this study cannot be made part of the curriculum of our colleges. The civil service of the state, unfortunately, does not at present hold out such inducemenis to college graduates as to justify special courses in this branch of knowledge.

There is but one conclusion. The study of municipal administration must be done, if at all, by intelligent citizens working without other inducement than their own patriotism and the desire to discharge that debt which every man owes to the community in which he lives. Fortunately, there is no lack of such citizens, and there is abundant evidence that the work has already been commenced. Articles are being written on the defects of our present municipal systems, and intelligent observers are reporting interesting municipal experiments abroad. Associations are being formed in various cities, having among their objects the instruction of the public in matters of municipal administration. If this work can be properly systematized, if the associations can do it thoroughly and scientifically and in correspondence with each other, there would seem to be no reason why there should not be a steady advance in the improvement of our municipal governments. An association in each city, with small committees, each investigating some particular branch of municipal work and studying the subject in the light of information gathered both at home and abroad, would be of great assistance to the city officials; and a league of such associations holding annual meetings would increase by co-operation the efficiency of all of them.

This is but applying to the science of municipal government the methods which are in practical use in other 
departments of knowledge, and it would turn into usefu! channels energy which is now, often at least, partially wasted.

In the city of Philadelphia, recently, the community was startled by the discovery of the dishonesty of a public official. The same investigation which disclosed his guilt, disclosed also a looseness of administration of state and city finances which gave opportunity to, if it did not suggest, the crime. Yet, while associations of public spirited citizens exerted strenuous efforts and expended money to secure from both political parties the nomination of an honest successor, none of them seemed to have turned their attention to the intelligent study of our financial system, and a comparison of it with other systems, with a view to making permanent improvements. Of the two, however, there can be no question but that the latter work would be of the most permanent benefit to the city. What we need is, not occasional spasms of public morality which will elect an honest candidate, but intelligent reform of our systems which shall secure uniform efficiency in our administrative machinery.

It is not necessary to discuss the methods to be adopted by associations for the study of municipal government. They will differ with each association. The work would, however, necessarily embrace :

First.-The collection and arrangement of literature on the subject, both official and unofficial, from all available sources.

Second.-The study of particular branches of municipal work by small committees making periodical reports.

Third.-The preparation of plans of improvement in municipal admintistration and efforts to secure the adoption of these plans.

Fourth.-Correspondence with other societies organized for similar purposes.

That this work would be laborious, and that it would involve long, patient and often apparently unproductive 
effort, is quite apparent. It cannot be carried on with the enthusiasm and immediate results of a political campaign. But if carried on with reasonable diligence, it would be of lasting benefit to the state.

It is patient study that tells in the long run. In undertaking it, we should remember the truth so well stated by Prof. Fiske, when he says:* "The amelioration of things will doubtless continue to be effected in the future as it has been effected in the past, not by ambitious schemes of sudden and universal reform (which the sagacious man always suspects, just as he suspects all schemes for returning a fabulously large interest upon investments), but by the gradual and cumulative efforts of innumerable individuals, each doing something to help or instruct those to whom his influence extends. He who makes two clear ideas grow where there was only one hazy one before, is the true benefactor of his species."

To substitute clear ideas of municipal government for the hazy ones now existing is a task worthy the attention of every intelligent citizen.

Philadelphia, Pa.

Frank P. Prichard.

"Preface to "Civil Government in the United States" 